TP Periodica Polytechnica

Social and Management

Sciences

25(1), pp. 64-69, 2017

DOI: $10.3311 /$ PPso.9331

Creative Commons Attribution (i)

RESEARCH ARTICLE

\section{Product Experiences and Consumer Preferences Related to the Choice of Yogurt}

\author{
Erika Hlédik ${ }^{1}$, Emma Lógó ${ }^{*}$
}

Received 13 April 2016; accepted after revision 02 June 2016

\begin{abstract}
Consumers can generally choose from a variety of products and brands within a product category. This article investigates product experiences and consumer preferences related to yogurt attributes, presents a two-step methodology. Exploratory research describes consumer preferences related to the choice of yogurt. Interview methodology was applied in the qualitative phase $(n=16)$. The quantitative research is based on these results. The questionnaire was applied to a group of young adults $(n=144)$. The main groups of consumer preferences were identified using factor analysis.
\end{abstract}

Keywords

product experience, consumer preference, product attribute

${ }^{1}$ Department of Ergonomics and Psychology, Faculty of Economic and Social Sciences, Budapest University of Technology and Economics

H-1521 Budapest, P.O.B. 91, Hungary

"Corresponding author, e-mail: emma@erg.bme.hu

\section{Introduction}

Yogurt is a relatively simple consumer food product. It does not have a complicated user interface and no special preparation procedures are followed when "end users" consume it. However, these products are presented in store cabinets in colourful packages, with well-developed brands, supplemented by several POS promotional tools, and significant price differences exist between brands. The main product functionality of yogurts is to serve as food. In addition, consumers' preferences toward different yogurt characteristics (e.g. organic, dietary product) can be associated with different product experiences. The aim of our research was to examine the connection between consumers' preferences of product characteristics and product experiences.

\section{Theoretical background: Framework of Product experience}

Before discussing the human-product experience as it relates to yogurt, it is important to summarize the theoretical background of the concept of product experience. Product experience always results from some kind of interaction between a user and a product. This interaction is not necessarily restricted to instrumental or non-instrumental physical action, but may also consist of passive (often visual) perception, or even remembering or thinking of a product (Desmet, 2002; Desmet and Hekkert, 2004; 2007). Human-product interaction and product experience are closely interwoven concepts. Figure 1 provides a model of human-product interaction (Hekkert and Schifferstein, 2008:p.3).

Humans are able to interact with their environment and products through their motor systems, sensory systems, cognitive systems and instincts. Yogurts interact with people on various different levels: visual appearance (the shape of the packaging, the colour of packaging or the yogurt, the texture of the product), tactual experience (with the tongue), auditory experience (when opening or shaking up the yogurt pot), smell and taste. (Cardello and Wise, 2008; Bárdos, 2007; Sekuler and Blake, 2000) Yogurts also interact with humans on more abstract, subjective, emotional or "symbolic" levels, as, for example, an 
aesthetic experience where "beauty" has a subjective meaning; or as a brand experience involving the producer's image or the consumer's self-image when she takes a yogurt pot off the shelf in a shop and brings it home; or on a social level (the experience of belonging to a group); or as a shopping experience; or in terms of satisfaction with the producer (Becker, 2011). It is clear that the product experience of yogurt extends far beyond the using or eating experience.



Fig. 1 Modell of human-product interaction (Source: Hekkert and Schifferstein, 2008)

Colours, shapes, sounds and words almost always have an emotional meaning (Izsó and Becker, 2011:pp.81-82). Emotional meaning partly innate but is also learned from our social and cultural environment. This is also, then, a question of design: design elements will only be successful if they hit the desired emotional spot. Nowadays producers sell complex product experiences rather than a simple food or ingredient, and designers thus have to plan experiences for customers (Pine and Gilmore, 1999). The whole development process of a product revolves around the consumers' product experience. Cues - sensory, verbal and visual stimuli - must be optimized not only at the level of product but also for the whole purchase and consumption process. In this area it is increasingly difficult to compete merely on the basis of the quality of the product, and therefore modern marketing approaches focus on consumers' emotional experiences. This new focus emphasizes a product's emotional and symbolic attributes in the positioning process and when taking decisions about product development which aim to impress the whole spectrum of senses of the customer. The colours, labels and signs on a yogurt cup convey a message which increases or decreases the product's subjective value. In order to be successful on the market, the brand of the yogurt must have a clear emotional place in the mind of the consumer. This emotional brand essence results from the sum of all experiences resulting from human-product interaction at both tangible and abstract levels (Rubinoff, 2004). The subsequent implementation of this in marketing and brand communication is derived from the emotional brand positioning.

Emotional brand essence is important in consumers decisions, because consumers cannot be perfectly informed about all product attributes. They might not get all relevant information, and might not know all possibilities regarding their preferences and financial situation. (Süle, 2012).

\section{Methodology}

Our methodology is based on 2 steps. First, the main product experiences of yoghurt consumption and shopping were explored, in a qualitative phase. After these characteristics of experience had been identified, in the second phase they were used to construct a questionnaire.

\subsection{Qualitative research}

The qualitative research phase aimed to explore the most important features of the yogurt consuming and buying habits of young consumers.

Our qualitative research was based on semi-structured indepth interviews ( $\mathrm{n}=16)$ with yogurt consumers aged 20 to 25 . Interviews were conducted in period 2010-2012 by help of the students of Budapest Business School. The guidelines of the interviews contained the following topics:

- associations and values concerning yogurt

- consuming and buying habits, preferences

- the ideal yogurt

\subsection{Qualitative Results}

In the qualitative phase we identified the 18 most important factors which consumers consider when thinking about yoghurts. When the participants mentioned a characteristic which may overlap in meaning with similar alternatives the results were noted under more than one category. For example, if a participant mentioned "low calorie content", we added it to the list along with "low carbohydrate content" and "low fat content" to the list of characteristics.

Table 1 Result of qualitative Phase (Source: own compilation)

\begin{tabular}{lll}
\hline & Explored Characteristics \\
\hline good quality & value for money & healthy \\
\hline fruit pieces & natural ingredients & $\begin{array}{l}\text { free from artificial } \\
\text { coloring agents }\end{array}$ \\
\hline creamy & $\begin{array}{l}\text { free from } \\
\text { preservatives }\end{array}$ & $\begin{array}{l}\text { free from artificial } \\
\text { flawours }\end{array}$ \\
\hline low fat content & well-known brand & Hungarian origin \\
\hline low calorie content & low carbohydrate & environmentally- \\
& content & friendly packaging \\
\hline with cream & organic & high fat content \\
\hline
\end{tabular}

\subsection{Quantitative study}

A study was conducted using 144 undergraduate student participants at the Budapest Business School (BGF) and the Budapest University of Technology and Economics (BME). The respondents were between 19 and 29 years old, with an average age of 23.00 years, and $72 \%$ were female. All participants were unaware of the purpose of the study. We used standardized questionnaire applying pen and paper (PPI) method. 
Respondents were asked to complete a self-administered questionnaire. 18 attitude questions were developed using the results of the exploratory qualitative research. Six point Likert scales were used to measure the importance of yoghurt functions. The Cronbach alfa coefficient for the 18 items was 0.792, which denotes good and acceptable internal reliability consistency.

$68 \%$ of the respondents consume a yogurt at least once a week. Consumer preference groups are identified through the analysis of general descriptive statistics of the yogurt-related preferences, and from attitude statements made about the yogurts selected on the basis of the interviews.

Participants were asked to complete a survey about their yoghurt preferences using a list of attributes and attribute levels. We defined 4 attributes: flavour, brand, fat content, and other. The numbers of levels assumed for attributes (characteristics) are as follows:

1) 10 brands: Cserpes, Danone, Jogobella, Milli, Mizo, Montice, Müller, Olma, Sole, Zott

Table 2 Brand Levels (Source: own compilation)

\begin{tabular}{llllll}
\hline \multirow{2}{*}{ Attribute 1. } & Levels & $\begin{array}{l}\text { Primarily } \\
\text { preferred } \\
(\%)\end{array}$ & $\begin{array}{l}\text { Preferred } \\
(\%)\end{array}$ & $\begin{array}{l}\text { Don't } \\
\text { Know } \\
(\%)\end{array}$ & $\begin{array}{l}\text { Rejected } \\
(\%)\end{array}$ \\
\hline & Cserpes & 6 & 14 & 70 & 10 \\
& Danone & 57 & 38 & 3 & 3 \\
& Jogobella & 18 & 67 & 12 & 3 \\
& Milli, & 0 & 30 & 61 & 9 \\
Mizo & 0 & 60 & 16 & 24 \\
& Montice & 0 & 11 & 81 & 8 \\
& Müller & 4 & 36 & 50 & 10 \\
& Olma & 0 & 6 & 83 & 11 \\
& Sole & 1 & 47 & 38 & 14 \\
& Zott & 3 & 60 & 28 & 9 \\
\hline
\end{tabular}

2) 9 flavours: strawberry, forest fruit, peach, sour cherry, raspberry, natural, vanilla, chocolate, caramel

Table 3 Flavour Levels (Source: own compilation)

\begin{tabular}{|c|c|c|c|c|c|}
\hline Attribute 2 . & Levels & $\begin{array}{l}\text { Primarily } \\
\text { preferred } \\
(\%)\end{array}$ & $\begin{array}{l}\text { Preferred } \\
(\%)\end{array}$ & $\begin{array}{l}\text { Don't } \\
\text { Know } \\
(\%)\end{array}$ & $\begin{array}{l}\text { Rejected } \\
(\%)\end{array}$ \\
\hline \multirow{9}{*}{ 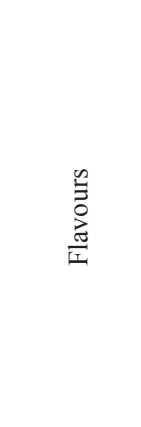 } & strawberry & 26 & 53 & 16 & 5 \\
\hline & forest fruit & 17 & 59 & 22 & 2 \\
\hline & peach & 10 & 64 & 17 & 9 \\
\hline & sour cherry & 14 & 56 & 20 & 10 \\
\hline & raspberry & 6 & 60 & 28 & 6 \\
\hline & natural & 6 & 42 & 17 & 35 \\
\hline & vanilla & 8 & 39 & 29 & 24 \\
\hline & chocolate & 8 & 39 & 32 & 21 \\
\hline & caramel & 2 & 18 & 40 & 40 \\
\hline
\end{tabular}

3) 3 types of fat content: $0.01 \%$ (diet), $1.5 \%$ (low) and $3.7 \%$ (high),

Table 4 Fat Content Levels (Source: own compilation)

\begin{tabular}{|c|c|c|c|c|c|}
\hline Attribute 3 . & Levels & $\begin{array}{l}\text { Primarily } \\
\text { preferred } \\
(\%)\end{array}$ & $\begin{array}{l}\text { Preferred } \\
(\%)\end{array}$ & $\begin{array}{l}\text { Don't } \\
\text { Know } \\
(\%)\end{array}$ & $\begin{array}{l}\text { Rejected } \\
(\%)\end{array}$ \\
\hline \multirow{3}{*}{ 苛 } & $0.01 \%$ (diet) & 49 & 43 & 7 & 1 \\
\hline & $1.5 \%$ (low) & 31 & 51 & 12 & 7 \\
\hline & $3.7 \%$ (high) & 2 & 50 & 17 & 31 \\
\hline
\end{tabular}

4) Finally 7 other characteristics were considered: creamy, fruit pieces, light, fruit flavour, with muesli, probiotic, organic.

Table 5 Other Characteristics Levels (Source: own compilation)

\begin{tabular}{|c|c|c|c|c|c|}
\hline Attribute 4 . & Levels & $\begin{array}{l}\text { Primarily } \\
\text { preferred } \\
(\%)\end{array}$ & $\begin{array}{l}\text { Preferred } \\
(\%)\end{array}$ & $\begin{array}{l}\text { Don't } \\
\text { Know } \\
(\%)\end{array}$ & $\begin{array}{l}\text { Rejected } \\
(\%)\end{array}$ \\
\hline \multirow{7}{*}{$\frac{\omega}{\stackrel{\omega}{ \pm}}$} & creamy & 24 & 63 & 9 & 3 \\
\hline & fruit pieces & 44 & 36 & 15 & 5 \\
\hline & light & 10 & 63 & 18 & 8 \\
\hline & fruit flavour & 3 & 62 & 29 & 6 \\
\hline & with muesli & 3 & 60 & 12 & 23 \\
\hline & probiotic & 6 & 53 & 17 & 13 \\
\hline & organic & 1 & 53 & 18 & 13 \\
\hline
\end{tabular}

Respondents were asked to determine their primary preference for each attribute (most preferred attribute level), secondary preferences (I will also consider), unacceptable levels (it is out of the question), and attributes and/or levels they don't know.

The 18 items of yogurt-related consumer preferences were subjected to principal component analysis (PCA) using SPSS. Prior to performing PCA the suitability of data for factor analysis was examined. The Kaiser-Meyer-Olkin (KMO) value was 0.71 , exceeding the recommended value of 0.6 and Barlett's Test of Sphericity reached statistical significance, which indicates that the factor analysis was appropriate.

Using Kaiser's criterion principal component analysis revealed the presence of six components with eigenvalues exceeding 1, which explained 27.8 per cent, 13.6 per cent, 9.9 per cent, 7.7 per cent, 6.9 per cent and 5.7 per cent of the variance respectively. To aid in the interpretation of these six components Varimax rotation was performed. As a result, six assessable and well separable factors were gained on the basis of the factor values. The six factors explained a total of 71.7 per cent of the variance.

Features belonging to the first component can be regarded as a preference for 'Naturalness'. (see Table 6) To be more precise, items 'without anything (bad) added' belong to this component, and these had a great (more than 0.8 ) factor weight (e.g. 
free from artificial colouring agents, free from Preservatives, free from artificial flavours). Moreover, further significant factor weights (above 0.5) were observed for the 'Natural ingredients' and 'Healthy' components. These factors were also supplemented by the statement on Environmentally friendly packaging.

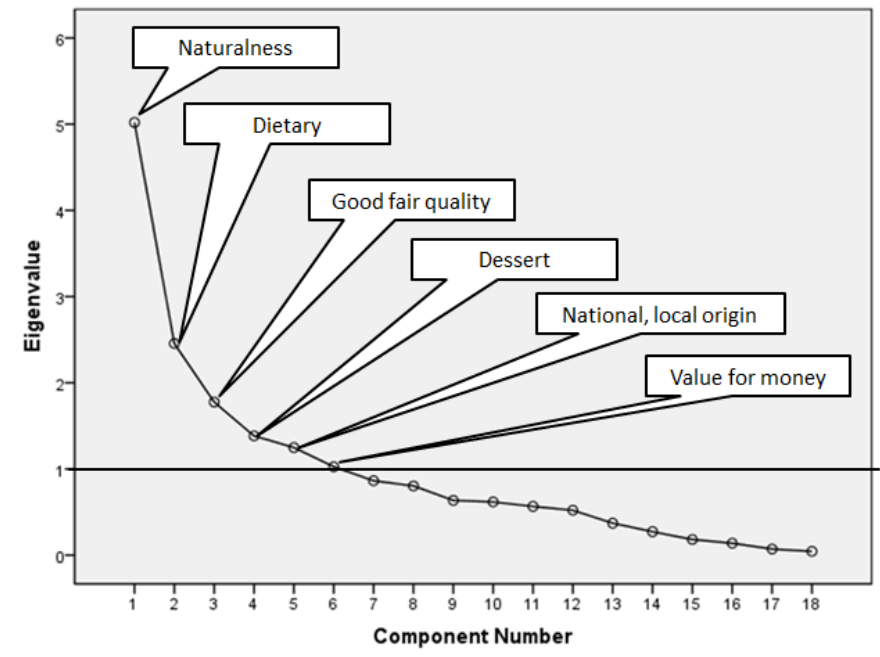

Fig. 2 Factors on scree plot (Source: SPSS)

Table 6 "Naturalness" factor - Statements and factor weight (Source: own compilation)

\begin{tabular}{ll}
\hline Statement & factor weight \\
\hline Free from artificial colouring agents & .886 \\
Free from preservatives & .878 \\
Free from artificial flavours & .811 \\
Natural ingredients & .732 \\
Healthy & .702 \\
Environmentally friendly packaging & .488 \\
\hline
\end{tabular}

The second component consists of features that represent the ' 'Dietary' nature of the yogurt. (see Table 7) All three items are present with a factor weight above 0.9: low fat content (0.911), low carbohydrate content (0.922) and low calorie content $(0.947)$ are represented in this component.

Table 7 "Dietary" factor - Statements and factor weight (Source: own compilation)

\begin{tabular}{ll}
\hline Statement & factor weight \\
\hline Low calorie content & .947 \\
Low carbohydrate content & .922 \\
Low fat content & .911 \\
\hline
\end{tabular}

The third component could be interpreted as the most widespread image of the yogurt in the consumers' mind as it is usually represented in advertisements and marketing communication. The 'Fruit pieces' and 'Well-known brand' items belong to this component with factor weights of more than 0.7 . (see Table 8) For many years in almost all marketing instruments fruit pieces have been depicted as an attractive feature of yogurt, and if a stable and well-known brand can also be attached to it together with a subjectively interpretable notion of good quality then this can be regarded as the general image of yogurt, placing it in the 'good fair quality' category in its positive sense as well as positioning the consumers of yogurt as discerning customers.

Table 8 "Good fair quality" factor - Statements and factor weight (Source: own compilation)

\begin{tabular}{ll}
\hline Statement & factor weight \\
\hline Fruit pieces & .751 \\
Known brand & .727 \\
Good quality & .520 \\
\hline
\end{tabular}

The 'Dessert' component (see Table 9) can be described as a preference for delicacies (a refined taste), and this is associated with the product features 'creamy' $(0.777)$ and 'with cream' $(0.807)$, i.e. preference for pleasant texture.

Table 9 "Dessert" factor - Statements and factor weight

(Source: own compilation)

\begin{tabular}{ll}
\hline Statement & factor weight \\
\hline With cream & .807 \\
Creamy & .777 \\
\hline
\end{tabular}

The fifth component includes the product features related to its national or local origin. (see Table 10) 'High fat content' (participating in the preference group with a factor weight of 0.766), supplemented by the 'Hungarian origin' and 'Organic' features and also Environmentally friendly packaging play a role in the Natural factor presented earlier are all components of this factor with a weight 0.467 . It describes a consumer preference in which preference for Hungarian origin, naturally high fat content, "hand-made" and/or organic products prevails.

Table 10 "National, local origin" factor - Statements and factor weight (Source: own compilation)

\begin{tabular}{ll}
\hline Statement & factor weight \\
\hline High fat content & .766 \\
Hungarian origin & .542 \\
Organic & .467 \\
\hline
\end{tabular}

The sixth component definitely embraces price sensitive consumer preferences that reflect a value for money consumer attitude, which can be interpreted in an entirely subjective way. (see Table 10) In addition to consumers looking for the most economic 
options by selecting the best priced own label products and the current cheapest special offers regardless of brand, this preference can also prevail in preferences of consumers who are not bargain hunters but who select higher positioned products if they feel they represent value for money. These are the target audience for ' 'buy in bulk cheaper' promotions or discounted branded offers as well as offers with free gifts attached to the product.

Table 11 "Value for money" - Statements and factor weight (Source: own compilation)

\begin{tabular}{ll}
\hline Statement & factor weight \\
\hline Value for money & .873 \\
\hline
\end{tabular}

\section{Summary}

Our research examined the connection between product features (including brand) and product experience. Neither the functions of yogurts in nutrition (e.g. as a dessert, drink, breakfast, salad ingredient etc.) nor functionality (e.g. re-sealable packaging, size, shape of pots etc.) were dealt with. Their role in product experience may also be important, so it is worth examining them in a forthcoming study.

We combined the yogurt experience factors with a model of human-product interaction. (see Fig. 3) 'Naturalness' can be regarded as belonging to the sensory properties, because almost every sign related to this appears on the product's packaging, and they can be perceived by eyesight. Possible indicators of consumer behaviour include the three factors, "good-fair quality", "National-local origin", and "Value for money". "Dietary" and "Dessert" factors refer to yogurt's functionality.

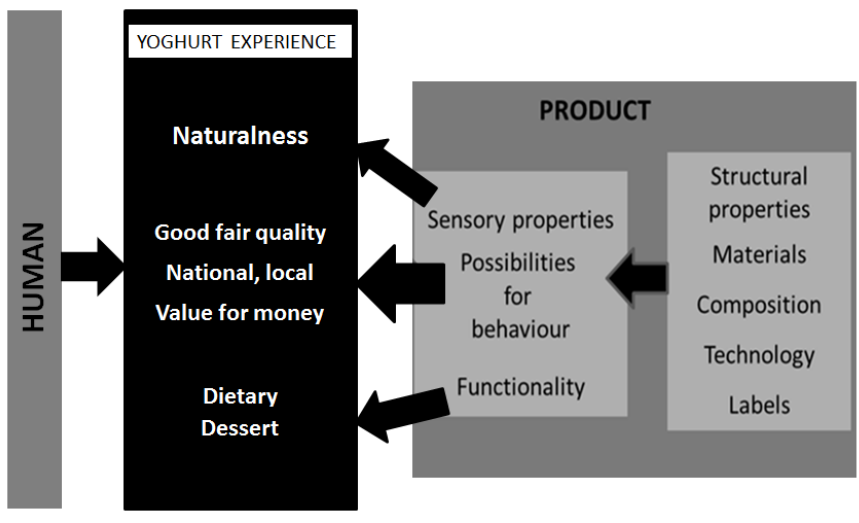

Fig. 3 Yoghurt Experience Factors and the model of Human-Product interaction (Source: own compilation)

There are several limitations to the examinations presented by this paper. One of the most important ones is the restricted age group of the participants in the study. Although the participants in the exploratory examination belonged to various age groups the second step was limited to a narrower age group and concentrated only on a smaller, and thus not representative sample consisting of 144 students in higher education.
Despite these reservations we believe that it was significant that in the case of a relatively simple product it was feasible to illustrate the complexity of the consumer/customer experience system behind making a decision on purchasing. Although the preferences of product characteristics gained as a result of the descriptive statistics cannot be generalised, they suggest that different preference systems co-exist in the consumers' minds about the characteristics of a single product. The customer preference groups formed by factor analysis illustrate how these relatively complicated and complex systems fit to a well-defined customer segment of a certain product, in this case the yogurt.

Having obtained promising results, we believe that this method might be extended to other age groups in terms of the yoghurts examined now and also to larger samples. Furthermore, it may also be applicable to examine experiences with other products and product lines, with the appropriate modifications.

Examining product experience is essential from the point of view of product management, because nowadays only companies that consciously deal with the complex experience of their customers and end-users when creating their products and services can operate successfully on the market. As was already noted in the introduction, these experiences are of vital importance, including product experience in consumers' decisions. In a world where there is a wide range of products with similar functions available for consumers who are disillusioned and tired of being exposed to making seemingly endless decisions - consumers whose behaviour is becoming more and more unpredictable and intangible, one of the most secure guiding points for companies in a competitive field is the need to present in the market by affecting the emotions and creating positive feelings with their products.

To conclude, we might assert that revealing and measuring consumer experiences plays important role in understanding consumer behaviour and especially the decision making process. Understanding product experiences can help product managers build more effective product strategy.

\section{References}

Bárdos, Gy. (2007). A kémiai érzékelés. (Chemical Sensation.) In: Csépe, V., Győri, M., Ragó, A. Általános Pszichológia I. Észlelés és Figyelem. (Psychology I. Perception and Attention), Osiris Kiadó, Budapest, pp. 448-465. (in Hungarian)

Becker, Gy. (2011). A tárgyak, a márkák, és az élmények. (Products, Brands, Experiences) In: Izsó, L., Becker, Gy. Termékélmény. (Product Experience), Akadémiai Kiadó, Budapest, pp. 15-66. (in Hungarian)

Cardello, A. V., Wise, P. M. (2008). Taste, smell and chemestries in product experience. In: Hekkert, P., Schifferstein, J. Product Experience, Elsevier, Oxford, pp. 91-132.

Desmet, P. M. A. (2002). Designing emotions. Delft University of Technology, Delft.

Desmet, P. M. A. (2007). Product emotion. In: Schifferstein, H. N. J., Hekkert, P. (eds.), Product experience. Elsevier Science Publishers. 
Desmet, P. M. A., Hekkert, P., Hillen, M. G. (2004). Values and emotions; an empirical investigation in the relationship between emotional responses to products and human values. In: Proceedings of Techné: Design Wisdom, 5th European Academy of Design conference, Barcelona, Spain.

Hekkert, P., Schifferstein, J. (2008). Introducing Product Experience. In: Hekkert, P., Schifferstein, J. Product experience. Elsevier, Oxford, pp. 1-8.

Izsó, L. (2011). A termék fogalma és föbb típusai. (Products definition and types) In: Izsó, L., Becker, Gy. Termékélmény. (Product Experience), Akadémiai Kiadó, Budapest, pp. 81-82. (in Hungarian)

Izsó, L., Becker, Gy. (2011). Termékélmény. (Product Experience), Akadémiai Kiadó, Budapest. (in Hungarian)
Pine, J. P., Gilmore, J. H. (1999). The Experience Economiy: Work is Theater \& Every Business a Stage. Harvard Business Press, Boston.

Rubinoff, R. (2004) How to Quantify The User Experience. URL: http://articles.sitepoint.com/print/quantify-user-experience

Sekuler, R., Blake, R. (2000). Észlelés. (Perception), Osiris Kiadó, Budapest. (in Hungarian)

Süle, M (2012). Advertising effects vs. consumer consciousness - Results of an empirical study. Periodica Polytechnica Social and Management Sciences. 20(2), pp. 91-103. https://doi.org/10.3311/pp.so.2012-2.04 